\title{
Development of New HS-SPME-GC-MS Technique to the Measurement of Volatile Terpenoid Profile of Milk
}

\author{
Rita Székelyhidi $^{1}$ (1) Erika Hanczné Lakatos ${ }^{1} \cdot$ Beatrix Sik $^{1} \cdot$ Zsolt Ajtony $^{1}$
}

Received: 8 July 2020 / Accepted: 16 June 2021 / Published online: 24 July 2021

(c) The Author(s) 2021

\begin{abstract}
This study presented the development of such a HS-SPME-GC-MS technique, with the use of which, directly from the raw milk sample matrix, both qualitatively and quantitatively; the volatile terpenoids ( $\alpha$-pinene, sabinene, $\beta$-pinene, p-cymene, limonene, linalool, $\alpha$-thujene, camphor, menthol, methyl chavicol, caryophyllene E, $\alpha$-humulene) can be determined, derived from herbs eaten by the dairy animals by different feeding methods. Repeatability was less than $10 \%$ in the case of milk fat samples. The estimated limits of quantitation were between 2 and $16 \mathrm{ng} / \mathrm{g}$. The lowest values were $2 \mathrm{ng} / \mathrm{g}$ for p-cymene and methyl chavicol; the highest value was $16 \mathrm{ng} / \mathrm{g}$ for caryophyllene. In the case of goat milk, the repeatability was better than $8 \%$ except for $\alpha$-thujene. The estimated limits of quantitation were between 1 and $8 \mathrm{ng} / \mathrm{g}$. The lowest values were $1 \mathrm{ng} / \mathrm{g}$ for $\beta$-pinene, p-cymene and limonene, and the highest value was $8 \mathrm{ng} / \mathrm{g}$ for linalool. In milk fat, the highest concentration was identified in caryophyllene E (470 ng/g) and $\alpha$-humulene $(430 \mathrm{ng} / \mathrm{g})$, while the lowest concentration was in p-cymene $(2 \mathrm{ng} / \mathrm{g})$ and camphor $(2 \mathrm{ng} / \mathrm{g})$. In goat milk, limonene was present in all samples, but its amount varied depending on the type of consumed herb. Methyl chavicol and caryophyllene E were detected in goat's milk only in one case. The former was detected in sage milk at $2.09 \mathrm{ng} / \mathrm{g}$ and the latter in tarragon milk at $2.28 \mathrm{ng} / \mathrm{g}$. We have also successfully demonstrated that the feed consumed by dairy animals also affects the quality of dairy products.
\end{abstract}

Keywords Volatile components · Terpenes · Gas chromatography $\cdot$ Mass spectrometry $\cdot$ SPME $\cdot$ Milk

\section{Introduction}

Solid-phase microextraction (SPME) is one of the fastestgrowing extraction techniques, due to its many advantages. The first is simplicity. It is easy to automate and the SPME module can be easily integrated into the automatic sample feeder of all types of gas chromatographs. In addition to its automated version, there is a manual arrangement with a cheaper and recyclable "holder" in which the thread can be replaced. SPME sampling can therefore also be performed manually, unlike other techniques, which provide high reproducibility and do not differ much from the automated version. Another great advantage of the method is the variety of fibre material, which increases the selectivity of sampling (Ho et al. 2011).

Rita Székelyhidi

szekelyhidi.rita@sze.hu

1 Department of Food Science, Faculty of Agricultural and Food Sciences, Széchenyi István University, Lucsony Street 15-17, 9200 Mosonmagyaróvár, Hungary
The analysis of aroma components in dairy products poses a complex problem due to the complexity of the sample matrix and the complexity of the most commonly used sample preparation procedures, such as vacuum distillation and liquid-liquid extraction (De Frutos et al. 1991; Mariaca and Bosset 1997; Lubbers et al. 1998; Sides et al. 2000).

Extraction tests are constantly being updated and new techniques are being invented to reduce extraction time, solvent and equipment requirements, increase sensitivity and ensure widespread applicability (Panseri et al. 2008).

Groups of chemical compounds that can be determined by SPME analysis contribute to the taste and smell of the products and act as an indicator if there is a change in quality or contamination in the product. The SPME process provides several uses for food volatile component testing.

SPME analysis of terpenoids in dairy products can determine the diet and region of origin of the animals (Abilleira et al. 2010; Cais-Sokolińska and Majcher, 2010; Erkaya and Şengül, 2011; Fernández-García et al. 2008; Majcher et al. 2010). Poulopoulou et al. (2012a, 2012b) studied sheep and goat milk and dairy products made from these milk by the 
SPME method. The study found that the terpenoids detected may appear in milk as biomarkers of the feed consumed. Although terpenes are critical compounds, their detection from milk samples by the SPME method is extremely difficult. This is due to the matrix effect of milk fat and the significantly different vapour pressures of each terpene (Abilleira et al. 2010).

Terpenoids can be transferred to dairy products mainly from digested plant food. Mono- and sesquiterpene compounds can be derived from plants into milk in two ways, via the digestive tract or via the respiratory tract. In the first case, the molecules are transferred from the plants to the rumen, where the terpenes may undergo a chemical transformation. All of these molecules are obtained from the plants into the rumen and are then absorbed from the rumen into the bloodstream, and from there transferred into the milk. Terpenes from plants, as well as those that arise in the rumen, are well detectable (Schlichtherle-Cerny et al. 2004). In the second case, the components spread through the air and enter the animal's lungs and from there into the blood (Viallon et al. 2000). Volatile components alter the intrinsic values of milk, especially the composition of microbiological and aromatic substances (Bugaud et al. 2001a; Viallon et al. 2000; Scehovic et al. 1998; Buchin et al. 1999).

The results show that milk from different production areas (highlands, lowlands) and seasons (winter, summer) differ from each other (Bugaud et al. 2001a; Scehovic et al. 1998; Buchin et al. 1999).

Feeding dairy animals is also an important factor in shaping the character of cheeses, as it influences milk-specific parameters such as milk fat, protein, taste, microflora and the function of lactic acid bacteria, which play a significant role in cheese making (Collomb et al. 1999; Grandison et al. 1985). Numerous studies describe that the milk of animals grazed on pastures overgrown with dicotyledons plant contains significantly higher amounts of aroma components than the milk of their counterparts fed hay, fodder or monocotyledonous plants (Dumont and Adda, 1978; Viallon et al. 1999). This difference is due to the presence of significant amounts of terpene compounds in dicotyledonous plants, especially mono- and sesquiterpenes (Mariaca et al. 1997).

Several research groups have found correlations between the organoleptic and physicochemical properties of cheeses and the place of production, animal feed and compounds derived from feed (Mariaca et al. 1997; Viallon et al. 1999, 2000; Bugaud et al. 2001a, b; Scehovic et al. 1998; Jeangros et al. 1997; Cornu et al. 2001; Buchin et al. 2002). Dumont and Adda (1978) found that sesquiterpene compounds appeared only in summer-made Beaufort cheeses when the dairy herd grazed on mountain pastures. Bugaud et al. (2001b) investigated terpene components from cheeses made from the milk of cows grazed in different areas. The results showed that the terpene profile of the studied cheeses was related to the botanical composition of the pastures. These compounds were present in significant amounts in mountain pastures where there are higher amounts of dicotyledons than in the plains, where predominantly monocotyledonous plants are present. A wide range of organic volatile components is responsible for the aroma of the cheeses. These components are very similar in different types of cheese, but there may be differences in their proportions (Ziino et al. 2005).

\section{Materials and Methods}

\section{Chemicals and Gases}

Sabinene (75\% purity), $p$-cimene (99\% purity), 4-allylanisol (98\% purity), $\alpha$-pinene (98\% purity), $\alpha$-humulene (96\% purity), $\beta$-pinene (99\% purity), cariofillene-E (98\% purity) and $\alpha$-thujone (96\% purity) were purchased from SigmaAldrich (Budapest, Hungary). Limonene (94\% putity), linalool (98\% purity), camphor (96\% purity), menthol (99\% purity) and methanol (99.8\% purity) were purchased from Merck (Budapest, Hungary). Helium was of $99.999 \%$ purity (Linde, Répcelak, Hungary).

\section{Plant Materials}

Several herbs and spices were chosen, such as milfoil (Achillea millefolium L.), chamomile (Matricaria chamomilla L.), woodruff (Galium odoratum L.), tarragon (Artemisia dracunculus L.), ribgrass (Plantago lanceolata L.) and sage (Salvia officinalis L.) which have favourable smell, aroma and physiological effect based on literature and folk observations.

\section{Sampling Procedures}

Investigations were carried out in different phases and the samples used came from two different premises to the site of analysis, Széchenyi István University, Faculty of Agricultural and Food Sciences, Analytical Laboratory of Department of Food Science. Samples from dairy cattle came from the premises of Bicskei Mezőgazdasági Zrt. (Bicske, Hungary) where the experimental animals were driven to pastures with various herbs and by grazing herbs there, and the herbal active ingredients to be tested were introduced to their body. Milk and blood samples after 10 days of grazing were derived from morning and evening milk of 2-2 experimental animals in which the blood was taken as well.

The grazing herbal active ingredients were introduced to the animal's body and milk. Cheese samples analysed in this study were made from the herbal milk of these 
animals. The herbal and natural Trappist cheese samples were analysed in a 4-day fresh and 6-week mature ageing time.

The goat feeding experiments were carried out at the farm of József Csató farmer at Kerta (Hungary). In this experiment, we have already done the feeding with accurate amounts. Samples were obtained from 3-3 experimental animals, which were kept away from other animals and were fed for 10-10 days with 6 different herbs. The mass of plants mixed with the feed was gradually increased from 40 to $50 \mathrm{~g}$ during the 10 days, to avoid straining the rumen of small ruminants. The goat milk samples were taken from the evening milking of day 10 of the feeding experiment. After the feeding experiments, the samples of milk, blood and cheese were delivered to the laboratory and were processed and analysed.

\section{Sample Preparation Procedures}

The sample preparation of blood samples is based on Estell et al. (2010) method with some modifications. Because only a small amount of blood samples could be yielded from cows, therefore, to ensure the minimum $5 \mathrm{~mL}$ of plasma required for the examinations, the samples from two cows were combined then centrifuged for $1 \mathrm{~h}$ at $5500 \mathrm{~g}$ in a sealed sampling tube (3 K, Sigma). Supernatant plasma was stored at $-20{ }^{\circ} \mathrm{C}$ until use.

During the sample preparation of cheese samples, $100 \mathrm{~g}$ of herbal and natural Trappist cheese was chopped for $10 \mathrm{~min}$ with a high-performance $(750 \mathrm{~W})$ electric kitchen grinder (Electrolux). After grinding, the cheese samples at 5-5 g were measured in $24-\mathrm{mL}$ vials with a screw cap (Sigma-Aldrich) and stored at $-20{ }^{\circ} \mathrm{C}$ until further use. To avoid the cross contaminations the vials were rinsed with methanol (Merck) and heated previously at $150{ }^{\circ} \mathrm{C}$ for $1 \mathrm{~h}$.

Separate the milk fat from the milk the two-step centrifugation procedure was applied (Abilleira és mtsai; 2010). During the first step, $80 \mathrm{~g}$ of preserved milk was centrifuged with $3300 \mathrm{~g}$ at $5{ }^{\circ} \mathrm{C}$ for $15 \mathrm{~min}$. Supernatant cream was further centrifuged (second step) in a sealed centrifugation tube at $35^{\circ} \mathrm{C}$ with $5500 \mathrm{~g}$ for $2.5 \mathrm{~h}(3 \mathrm{~K}$, Sigma) and then supernatant milk fat was stored at $-20{ }^{\circ} \mathrm{C}$ until use.

The fat content of the butter sample from the retail trade was separated from the aqueous phase after thawing and centrifugation at $35{ }^{\circ} \mathrm{C}$ at $5500 \mathrm{~g}$ for $1 \mathrm{~h}(3 \mathrm{~K}$, Sigma).

After receiving the goat milk samples, 5-5 g was measured in $24-\mathrm{mL}$ vials with a screw cap and stored at $-20{ }^{\circ} \mathrm{C}$ until further use. To avoid cross-contamination, the vials were flushed with methanol and heated previously at $150{ }^{\circ} \mathrm{C}$ for $1 \mathrm{~h}$.

\section{SPME Sampling Procedures}

The extraction of volatile components was performed by SPME method and headspace (HS) analysis. For the sampling procedure, a Supelco handheld SPME sampler $(57,330-\mathrm{U})$ was used. To analyse the volatile compounds of herbs and feeds, a 1-cm-long 100- $\mu \mathrm{m}$ PDMS-coated fibre was applied. For the HS analysis of blood plasma, milk, milk fat and cheese samples, a 2-cm-long 50- $\mu$ m divinylbenzene 30- $\mu \mathrm{m}$ carboxen polydimethylsiloxane-coated (DVB/ CAR/PDMS) StableFlex fibre was used, as recommended by the manufacturer (Supelco) for the trace analysis of volatile compounds. To remove the volatile components trapped in the SPME fibres from the air during storing, the fibres were heated at $260{ }^{\circ} \mathrm{C}$ for $15 \mathrm{~min}$ in our GC-MS injector. Samples are taken according to the data in Table 1.

\section{Gas Chromatography-Mass Spectrometry (GC-MS) System}

To analyse the volatile components of herbs, GCQ (Finnigan MAT) type ion trap was used, while for headspace analysis of plasma, milk and milk fat, QP-5000 (Shimadzu) type equipped with a quadruple analyser, gas chromatography-mass spectrometry systems were used. The test conditions used are listed in Table 2.

\section{Calibration of the Measuring Equipment}

The calibration of the developed GC-MS method with standard addition procedure was carried out by analysing spiked milk fats obtained from a sample of butter from retail trade and of spiked raw goat milk. The spiked samples were prepared as follows: in 24-mL vials, we weighted 5-5 g of milk fat obtained from butter from retail trade and 5-5 g

Table 1 Conditions used during SPME sampling for herbs, blood plasma, cow's milk and cheese

\begin{tabular}{|c|c|c|c|c|c|}
\hline & Herb & Plasma & Milk fat & Goat milk & Cheese \\
\hline SPME fibre & $\begin{array}{l}1 \mathrm{~cm}, \\
100 \mu \mathrm{m} \\
\text { PDMS }\end{array}$ & \multicolumn{4}{|c|}{$2 \mathrm{~cm}, 50 / 30 \mu \mathrm{m}$ DVB/CAR/PDMS } \\
\hline $\begin{array}{l}\text { Volume of the } \\
\text { vial }\end{array}$ & $43 \mathrm{~mL}$ & $24 \mathrm{~mL}$ & & & \\
\hline $\begin{array}{l}\text { Mass of the } \\
\text { sample }\end{array}$ & $2 \mathrm{~g}$ & $5 \mathrm{~g}$ & & & \\
\hline $\begin{array}{l}\text { Pretreatment } \\
\text { and sampling } \\
\text { temperature }\end{array}$ & $55^{\circ} \mathrm{C}$ & $40^{\circ} \mathrm{C}$ & $80^{\circ} \mathrm{C}$ & $60^{\circ} \mathrm{C}$ & $60^{\circ} \mathrm{C}$ \\
\hline $\begin{array}{l}\text { Pretreatment } \\
\text { time }\end{array}$ & $50 \mathrm{~min}$ & & & & \\
\hline $\begin{array}{l}\text { Sampling time } \\
\text { Mixing }\end{array}$ & $\begin{array}{l}5 \text { min } \\
\text { none }\end{array}$ & $\begin{array}{l}60 \mathrm{~min} \\
\text { none }\end{array}$ & $\begin{array}{l}50 \mathrm{~min} \\
\text { none }\end{array}$ & $\begin{array}{l}60 \mathrm{~min} \\
6001 / \mathrm{min}\end{array}$ & $\begin{array}{l}60 \mathrm{~min} \\
\text { none }\end{array}$ \\
\hline
\end{tabular}


Table 2 Test conditions for GC-MS analyses for herbs, blood plasma, cow's milk and cheese

\begin{tabular}{llll}
\hline & GCQ (herb) & $\begin{array}{l}\text { QP-5000 (blood plasma, } \\
\text { milk fat, cheese) }\end{array}$ & QP-5000 (goat milk) \\
\hline Injector & $280{ }^{\circ} \mathrm{C}$, split, $1: 30$ & $260{ }^{\circ} \mathrm{C}$, splitless, $5 \mathrm{~min}$ & $260{ }^{\circ} \mathrm{C}$, splitless $4 \mathrm{~min}$ \\
Desorption time & $5 \mathrm{~min}$ & $5.5 \mathrm{~min}$ & $4.5 \mathrm{~min}$ \\
Liner & $2 \mathrm{~mm} \mathrm{ID}$, quartz & $0.75 \mathrm{~mm}$ ID, glass & \\
Column & $\mathrm{RTX}-5$ (Restek) $30 \mathrm{~m}, 0.25 \mathrm{~mm} \mathrm{ID}, 0.25-\mu \mathrm{m} \mathrm{film}$ & \\
Temperature programme & $50-200{ }^{\circ} \mathrm{C}, 3{ }^{\circ} \mathrm{C} / \mathrm{min}$ & $50-185^{\circ} \mathrm{C}, 3{ }^{\circ} \mathrm{C} / \mathrm{min}$ & $40-160{ }^{\circ} \mathrm{C}, 3{ }^{\circ} \mathrm{C} / \mathrm{min}$ \\
Carrier gas & $\mathrm{He}(5.0, \mathrm{Linde}), 35 \mathrm{~cm} / \mathrm{s}$ & & \\
Ion source & $\mathrm{EI}, 70 \mathrm{eV}, 200{ }^{\circ} \mathrm{C}$ & & \\
\hline
\end{tabular}

of raw goat milk. I melted the fats in a $40{ }^{\circ} \mathrm{C}$ water bath, while directly after weighing, 50-50 $\mu \mathrm{L}$ methanol solution containing terpenes in $0.02-1.2 \mu \mathrm{g} / \mathrm{g}$ concentration was added to the raw goat milk. The vials were sealed and mixed throughout with vortex (VELP Scientifica $\mathrm{Rx}^{3}$, Italy). Samples were taken from the headspace of the spiked milk fat samples at $80{ }^{\circ} \mathrm{C}$ with a sampling time of $50 \mathrm{~min}$, whereas from spiked raw goat milk samples at $60{ }^{\circ} \mathrm{C}$ with a sampling time of $60 \mathrm{~min}$, and the sampling SPME fibres were taken into the injector of the GC-MS instrument. A straight line was drawn, with the method of least squares on the peak areas of ion chromatograms recorded in GC-MS selected ion monitoring (SIM) mode and on their respective terpene concentrations for value pairs. From the slope of the fitted lines, the sensitivity of the method and the lower limit of quantitation were determined (LOQ).

$\mathrm{LOQ}=10 \times S D / m$

where $S D$ is the standard deviation of the areas below the peak, and.

$m$ is the slope of the fitted calibration line.

Table 3 Mass to charge ratio $(\mathrm{m} / \mathrm{z})$, retention times $\left(t_{R}\right)$, linear ranges of analytical measurement curves, average slope and standard deviation $( \pm \mathrm{SD})$, and correlation coefficients of ions used for GC-MS quantitation of terpenes in case of milk fat samples. Analytical performance data for headspace analysis of dairy milk fat samples in
For qualitative determination of volatile terpenes in milk fat and raw goat milk samples, the retention times of volatile components and their mass spectrum recorded in the fullscan mode were compared with the retention time of the volatile components of each herb and with the mass spectra of NIST MS database. For quantitative determination of volatile terpene content of samples, the measuring equipment in SIM mode was calibrated, with standard addition method, in the case of milk fat for eleven and in the case of raw goat milk for twelve terpenes within the concentration range shown in Table 3, on 8 different concentrations. The standard terpene compounds used to calibrate the analysis of milk fat samples, the mass to charge ratio $(\mathrm{m} / \mathrm{z})$ of the ions used for their quantification, the retention time of the terpenes, and the linear ranges of analytical measurement curves, slopes and correlation coefficients $(\mathrm{R})$ for each terpene, are shown in Table 3.

The repeatability of the measurements was given by the corrected empirical standard deviation of the concentration values obtained by three and three parallel analysis of the spiked milk fat and raw goat milk samples. The measured average concentration

SPME (Cad, additive concentration (ng/g); RSD (\%), relative corrected empirical standard deviation of peak areas measured in parallel analyses $(\mathrm{n}=3) ; L O Q$, the estimated limit of quantitation of the method)

\begin{tabular}{|c|c|c|c|c|c|c|c|c|c|}
\hline No & Volatile component & $\mathrm{m} / \mathrm{z} \mathrm{Th}$ & $t_{R}(\min )$ & Linear range (ng/g) & Slope \pm SD (g/ng) & $\mathrm{R}$ & $\mathrm{C}_{\mathrm{ad}}(\mathrm{ng} / \mathrm{g})$ & $\operatorname{RSD}(\%)$ & LOQ (ng/g) \\
\hline 1 & $\alpha$-Pinene & 93 & 7.63 & $10-1000$ & $4550 \pm 64$ & 0,999 & 46 & 3.2 & 3 \\
\hline 2 & Sabinene & 93 & 9.02 & $5-770$ & $3472 \pm 38$ & 0,999 & 23 & 6.6 & 3 \\
\hline 3 & $\beta$-Pinene & 93 & 9.13 & $10-1230$ & $2857 \pm 74$ & 0,997 & 141 & 3.6 & 4 \\
\hline 4 & $p$-Cymene & 119 & 11.00 & $10-1000$ & $6216 \pm 86$ & 0,999 & 65 & 9.5 & 2 \\
\hline 5 & Limonene & 93 & 11.14 & $10-1000$ & $2007 \pm 36$ & 0,998 & 143 & 9.8 & 4 \\
\hline 6 & Linalool & 93 & 14.25 & $10-1000$ & $945 \pm 12$ & 0,999 & 98 & 6.1 & 8 \\
\hline 7 & $\alpha$-Thujene & 110 & 14.48 & $10-1000$ & $797 \pm 14$ & 0,998 & 66 & 8.6 & 6 \\
\hline 8 & Camphor & 95 & 16.19 & $10-1000$ & $1418 \pm 26$ & 0,998 & 47 & 6.7 & 4 \\
\hline 9 & Methyl chavicol & 148 & 18.61 & $10-1000$ & $6640 \pm 188$ & 0,994 & 16 & 12.9 & 2 \\
\hline 10 & Caryophyllene E & 133 & 28.06 & 20-2000 & $276 \pm 8$ & 0,994 & 388 & 2.5 & 16 \\
\hline 11 & $\alpha$-Humulene & 93 & 29.50 & $20-2000$ & $1576 \pm 42$ & 0,995 & 136 & 3.4 & 6 \\
\hline
\end{tabular}


of terpenes in the milk fat with repeatability and the estimated limits of quantitation for the 10:1 signal-noise ratio are shown in Table 3 . Repeatability was less than $10 \%$ except for methyl chavicol. The estimated limits of quantitation were between 2 and $16 \mathrm{ng} / \mathrm{g}$. The lowest values were $2 \mathrm{ng} / \mathrm{g}$ for $p$-cymene and methyl chavicol, and the highest value was $16 \mathrm{ng} / \mathrm{g}$ for caryophyllene.

The standard terpene compounds used to calibrate the analysis of raw goat milk samples, the mass/charge of the ions used for their quantitation, the retention time of the terpenes, and the linear ranges of analytical measurement curves, slopes and correlation coefficients (R) for each terpene, are shown in Table 4.

During the calibration with goat milk, the highest sensitivity was for $p$-cymene $(10,817 \pm 96 \mathrm{~g} / \mathrm{ng})$ and methyl chavicol $(9969 \pm 161 \mathrm{~g} / \mathrm{ng})$, and the lowest for caryophyllene $(1733 \pm 35 \mathrm{~g} / \mathrm{ng})$ and camphor $(1875 \pm 34 \mathrm{~g} / \mathrm{ng})$. Low uncertainties in the slope of analytical curves fitted to measurement points during calibration and the correlation coefficients greater than 0.996 for fitted lines all prove the adequate accuracy of my calibration.

The measured average concentration of terpenes in the raw goat milk with repeatability and the estimated limits of quantitation for the 10:1 signal-noise ratio are shown in Table 4. In the case of goat milk, the repeatability was better than $8 \%$ except for $\alpha$-thujene. The estimated limits of quantitation were between 1 and $8 \mathrm{ng} / \mathrm{g}$. The lowest values were $1 \mathrm{ng} / \mathrm{g}$ for $\beta$-pinene, $p$-cymene and limonene, and the highest value was $8 \mathrm{ng} / \mathrm{g}$ for linalool.

\section{Results and discussion}

\section{Optimisation of SPME Sampling Conditions}

A quantitative study of terpene-like volatile components was done with 2-cm-long 50/30- $\mu \mathrm{m}$ DVB/CAR/PDM fibre by SPME sampling of the headspace of the butter fat obtained from each milk sample and of the raw goat milk samples. The dependence of sampling temperature and sampling time of fibre-dissolved terpenes and terpene derivatives was investigated for optimal SPME sampling conditions.

For buttermilk sample, the optimal headspace sampling temperature was determined by the headspace analysis of $5-5 \mathrm{~g}$ of butter spiked with terpenes at 40,60 and $80{ }^{\circ} \mathrm{C}$ temperatures with 60-min sampling period.

The determination of optimal sampling time from headspace of spiked butter samples took place at $80{ }^{\circ} \mathrm{C}$ and for $1,2,5,10,20,30$ and $50 \mathrm{~min}$, while from headspace of spiked raw goat milk at $60^{\circ} \mathrm{C}$ and for $1,2,5,10,15,20,40$ and $60 \mathrm{~min}$.

When analysing milk fat samples, the largest of the three different HS-SPME samples taken at 40,60 and $80^{\circ} \mathrm{C}$ provided $80{ }^{\circ} \mathrm{C}$ with the best sensitivity of my measurements and the fastest equilibrium state. The optimal sampling time was determined by sampling $1,2,5,10,20,30,40$ and 50 min of terpene-added milk fat headspace and plotting of each terpene normed peak area's dependence from sampling time (Fig. 1).

In the case of spiked raw goat milk, out of the three different 40,60 and $80{ }^{\circ} \mathrm{C}$ SPME sampling temperatures, $40{ }^{\circ} \mathrm{C}$ has not yet provided sufficient sensitivity for less volatile components while at $80{ }^{\circ} \mathrm{C}$ the "skin" of the surface of the
Table 4 Mass to charge ratio $(\mathrm{m} / \mathrm{z})$, retention times $\left(\mathrm{t}_{\mathrm{R}}\right)$, linear ranges of analytical measurement curves, average slope and standard deviation $( \pm \mathrm{SD})$, and correlation coefficients $(\mathrm{R})$ of ions used for GC-MS quantitation of terpenes in case of goat milk samples. Analytical performance data for headspace analysis of spiked dairy milk fat samples in SPME ( $C_{a d}$, additive concentration (ng/g); RSD (\%), relative corrected empirical standard deviation of peak areas measured in parallel analyses $(\mathrm{n}=3) ; L O Q$, the estimated limit of quantitation of the method)

\begin{tabular}{|c|c|c|c|c|c|c|c|c|c|}
\hline No & Volatile component & $\mathrm{m} / \mathrm{z}(\mathrm{Th})$ & $t_{R}(\min )$ & Linear range (ng/g) & Slope $( \pm$ SD) $(g / n g)$ & $\mathrm{R}$ & $\mathrm{C}_{\mathrm{ad}}(\mathrm{ng} / \mathrm{g})$ & $\operatorname{RSD}(\%)$ & LOQ (ng/g) \\
\hline 1 & $\alpha$-Pinene & 93.10 & 9.70 & $5-1040$ & $3115 \pm 71$ & 0.996 & 29 & 7.5 & 3 \\
\hline 2 & Sabinene & 93.05 & 11.38 & $10-1320$ & $2610 \pm 45$ & 0.997 & 43 & 7.8 & 3 \\
\hline 3 & $\beta$-Pinene & 93.15 & 11.48 & $5-1370$ & $3282 \pm 83$ & 0.996 & 31 & 6.7 & 1 \\
\hline 4 & p-Cymene & 119.15 & 13.67 & $15-1300$ & $10,817 \pm 96$ & 0.997 & 56 & 7.5 & 1 \\
\hline 5 & Limonene & 68.10 & 13.83 & $10-1270$ & $5421 \pm 32$ & 0.998 & 38 & 5.7 & 1 \\
\hline 6 & Linalool & 71.10 & 17.23 & $10-1300$ & $3437 \pm 15$ & 0.998 & 51 & 7.4 & 8 \\
\hline 7 & $\alpha$-Thujene & 81.15 & 17.49 & $15-1530$ & $2235 \pm 12$ & 0.998 & 71 & 9.3 & 6 \\
\hline 8 & Camphor & 95.15 & 19.29 & $10-1400$ & $1875 \pm 34$ & 0.999 & 40 & 7.8 & 2 \\
\hline 9 & Menthol & 71.10 & 20.66 & $10-1425$ & $2788 \pm 81$ & 0.999 & 43 & 7.8 & 2 \\
\hline 10 & Methyl chavicol & 148.2 & 21.84 & $10-1370$ & $9969 \pm 161$ & 0.998 & 44 & 7.2 & 2 \\
\hline 11 & Caryophyllene E & 69.15 & 31.42 & $5-1470$ & $1733 \pm 35$ & 0.999 & 34 & 7.7 & 2 \\
\hline 12 & $\alpha$-Humulene & 93.15 & 32.85 & $5-1350$ & $5196 \pm 69$ & 0.998 & 29 & 7.0 & 2 \\
\hline
\end{tabular}


Fig. 1 Dependence of GC-MS normed peak area of volatile components on sampling time $\left(\mathrm{T}=80{ }^{\circ} \mathrm{C}\right.$ ) in cattle milk fat SPME headspace sampling

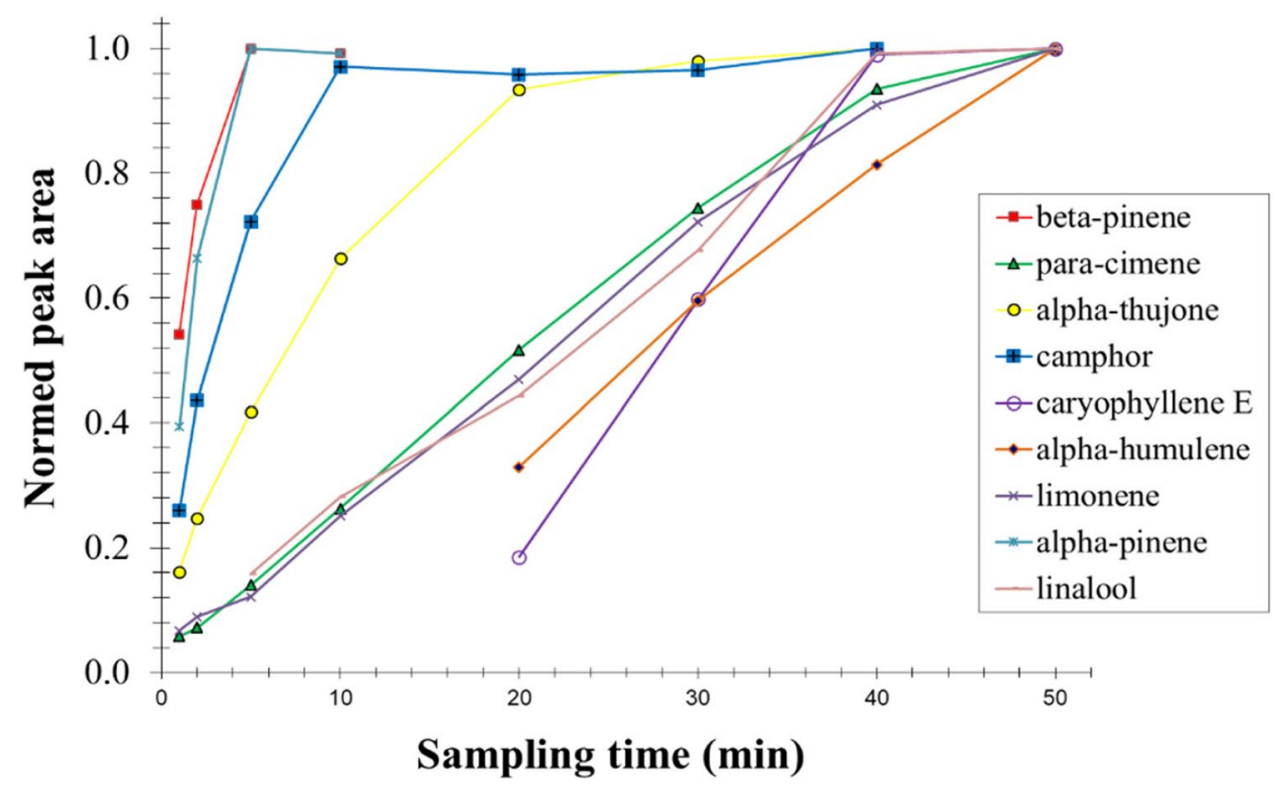

sample had already reduced the sensitivity; therefore, for my analysis, the SPME headspace sampling was carried out at $60{ }^{\circ} \mathrm{C}$ while mixing the sample. The optimal sampling time was determined by sampling 1, 2, 5, 10, 20, 30, 40 and 50 min of terpene-spiked goat milk headspace and by plotting each terpene normed peak area's dependence from sampling time (Fig. 2).

In the case of milk fat samples, it can be well seen (Fig. 1) that volatile $\beta$-pinene reached its peak, that is, its equilibrium state after $5 \mathrm{~min}$, camphor after 10, $\alpha$-thujene after 20 and caryophyllene after $40 \mathrm{~min}$. Surprisingly, the equilibrium state of $p$-cymene, which is more volatile than caryophyllene, reached the equilibrium state only after $50 \mathrm{~min}$. Although $\alpha$-humulene did not reach full equilibrium state even after $50 \mathrm{~min}$, longer sampling time did not significantly increase sensitivity, but it has significantly reduced the productivity of the measurements. Considering the above, the 50-min sampling time was chosen for milk fat samples.

In the case of spiked raw goat milk, it can be well seen on Fig. 2 that more volatile $\beta$-pinene, camphor, $\alpha$-thujene,
Fig. 2 Dependence of GC-MS peak area of volatile components on sampling time $\left(\mathrm{T}=60^{\circ} \mathrm{C}\right.$ ) in goat milk SPME headspace sampling

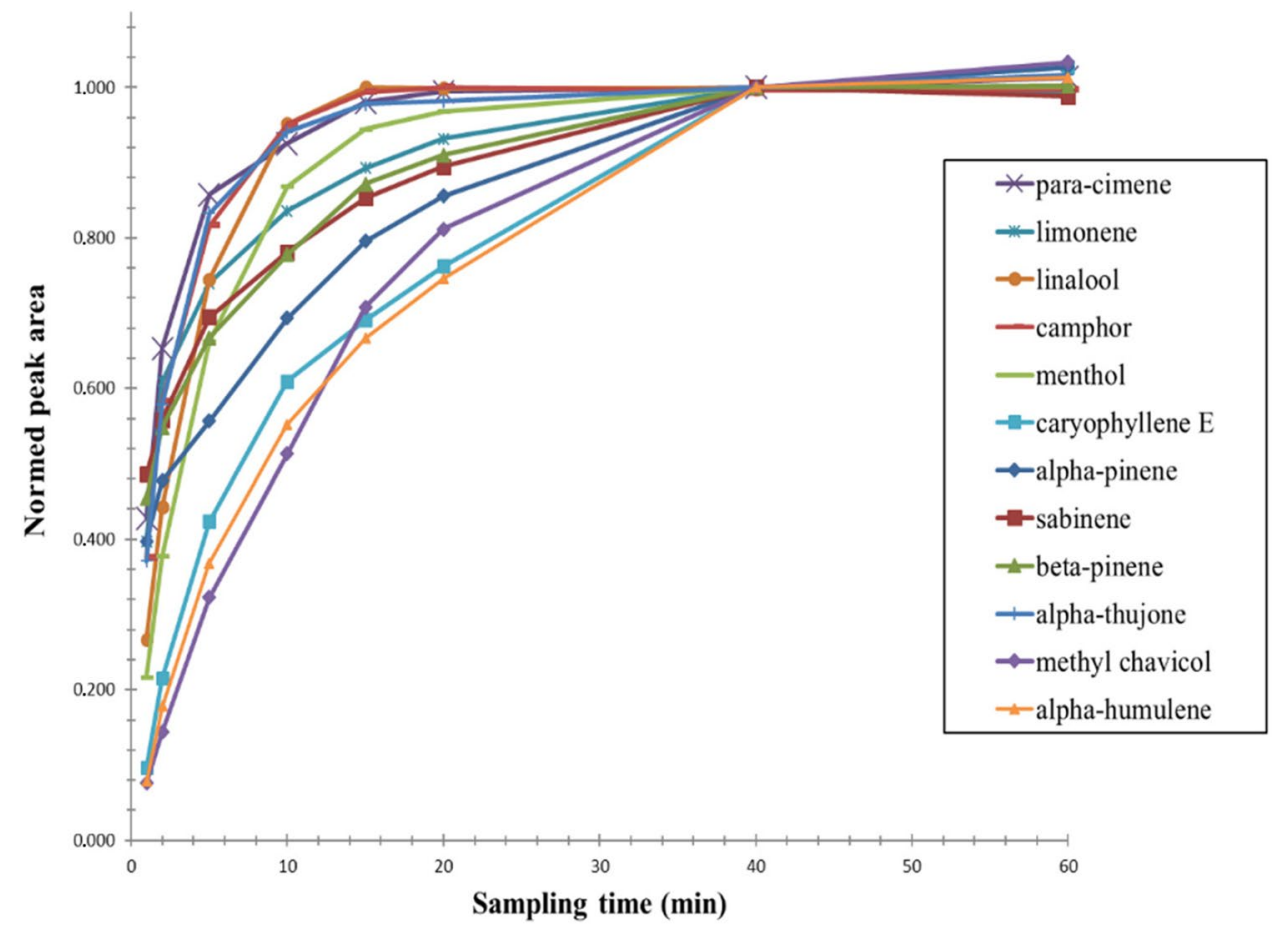


Table 5 Number of samples containing the tested terpenes in concentrations greater than the limit of detection $(\mathrm{N})$, minimum, maximum, mean, standard deviation and median of terpene concentrations in milk fat

\begin{tabular}{lllllll}
\hline & \multicolumn{9}{l}{ Terpene concentrations (ng/g) } \\
\cline { 2 - 7 } & $\mathrm{N}$ & Min & Max & Mean & $\begin{array}{l}\text { Standard devia- } \\
\text { tion }\end{array}$ & Median \\
\hline$\alpha$-Pinene & 28 & 4 & 79 & 18 & 16 & 17 \\
Sabinene & 9 & 2 & 28 & 11 & 10 & 10 \\
$\beta$-Pinene & 11 & 3 & 104 & 36 & 31 & 33 \\
p-Cymene & 16 & 2 & 9 & 4 & 2 & 3 \\
Limonene & 26 & 3 & 114 & 38 & 28 & 33 \\
Camphor & 4 & 3 & 7 & 4 & 2 & 3 \\
Methyl chavicol & 8 & 2 & 39 & 8 & 13 & 10 \\
Caryophyllene E & 13 & 39 & 470 & 127 & 116 & 121 \\
$\alpha$-Humulene & 28 & 3 & 430 & 46 & 83 & 64 \\
\hline
\end{tabular}

$\alpha$-pinene, sabinene, $\mathrm{p}$-cymene, limonene, linalool and menthol already reached the maximum of its peak area after $20 \mathrm{~min}$ that is its equilibrium state. Not surprisingly, the less volatile methyl chavicol, caryophyllene and humulene reached its equilibrium state only after $40 \mathrm{~min}$. Nevertheless, the 60-min sampling time was chosen in the case of goat milk samples, which ensured adequate repeatability only with the used sampling time, which was probably due to the sensitivity of a small amount of terpene compound found in milk samples to environmental parameters.

\section{Terpenes in the Milk Fat of Cows Fed with a Mixture of Different Herbs}

During the analysis of the milk fat content of the milk samples, among the volatile components of herbs, $\alpha$-pinene and $\alpha$-humulene from 28 , limonene from 26, $p$-cymene from 16 , caryophyllene $\mathrm{E}$ from $13, \beta$-pinene from 11 , sabinene from 9 , methyl chavicol from 8 , and camphor from 4 samples were quantified. In milk fat, the highest concentration was identified in caryophyllene E (470 ng/g) and $\alpha$-humulene (430 ng/g), while the lowest concentration was in $p$-cymene $(2 \mathrm{ng} / \mathrm{g})$ and camphor (2 ng/g) (Table 5). The presence of most of the identified components has already been reported in the case of milk or cheeses (Dumont and Adda, 1978; Guichard et al. 1987; Buchin et al. 1999; Viallon et al. 1999, 2000; Fernandez et al. 2003). Borge et al. (2016) compared the terpene content of creams made from the milk of grazed and barn-fed cows. Samples from barn-fed and grazed cows also showed $\alpha$-pinene and limonene; however, the amount of $\alpha$-pinene was significantly higher in the samples of grazed individuals, while the amount of limonene was significantly higher in the samples of individuals fed in the barn. Based on the results in the literature (Buchin et al. 1999) and ours, it can be stated that limonene is one of the most characteristic monoterpenes in milk and dairy products as it is present in most plants.

\section{Volatile Terpenes in Goats' Milk Fed with Various Herbs}

The proportion of mono- and sesquiterpene compounds in milk depends on the composition of the same compounds in the animal feed (Viallon et al. 2000; Bugaud et al. 2001a). However, the quantitative and qualitative analyses of the terpene components until now could only be made from the fat fraction separated from the raw milk. However, the new HS-SPME-GC-MS analytical method was developed to allow the quantitative and qualitative quantitation of terpenoids directly from the raw milk sample matrices; thus, the analysis does not require any preliminary sample preparation procedure. Terpene concentrations and standard deviation (ng/g) of goat milk samples from goat feeding experiments are shown in Table 6.

De Noni and Battelli (2008) also found that the botanical composition of different pastures causes changes in the terpene profile of milk and cheeses. This result is consistent with the results presented that the terpene composition of milk is changed when cows and goats are fed different herbs.

\section{Volatile Terpene Content in Blood Plasma of Dairy Cattle Fed with Herbs Spiked Feed and in Cheese Made from Herbal Milk}

In the case of blood plasma samples, there is a high probability of precipitation of plasma proteins above $40{ }^{\circ} \mathrm{C}$ that is why were performed headspace sampling at the highest temperature which is still considered safe at $40{ }^{\circ} \mathrm{C}$. The terpenes identified and defined in the plasma of cows fed with herbs and their retention times are shown in Table 7.

Boyle et al. (2002) examined the amount of cineole in the blood of brushtail possums which consuming eucalyptus using the SPME sampling procedure. 
Table 6 Terpene concentration of herbal goat milk samples and standard deviation of results $(\mathrm{ng} / \mathrm{g}),(\mathrm{n}=3)$

\begin{tabular}{lllllllll}
\hline No & Volatile component & \multicolumn{2}{l}{ Concentration \pm standard deviation $(\mathrm{n}=3), \mu \mathrm{g} / \mathrm{g}$} \\
\cline { 3 - 9 } & & Control & Milfoil & Sage & Woodruff & Camomile & Tarragon & Plantain \\
\hline 1 & $\alpha$-Pinene & $2.05 \pm 0.06$ & n.d & $15.06 \pm 0.06$ & $1.47 \pm 0.09$ & $13.14 \pm 0.07$ & $3.35 \pm 0.03$ & $7.23 \pm 0.05$ \\
2 & Sabinene & $2.02 \pm 0.09$ & n.d & $5.19 \pm 0.09$ & n.d & $6.32 \pm 0.06$ & n.d & $3.47 \pm 0.04$ \\
3 & $\beta$-Pinene & n.d & n.d & $7.23 \pm 0.05$ & $1.32 \pm 0.08$ & $7.19 \pm 0.04$ & $1.28 \pm 0.09$ & $2.41 \pm 0.03$ \\
4 & p-Cymene & $2.11 \pm 0.09$ & n.d & $34.42 \pm 0.09$ & $1.15 \pm 0.09$ & $40.35 \pm 0.09$ & $1.12 \pm 0.05$ & $23.39 \pm 0.14$ \\
5 & Limonene & $13.15 \pm 0.07$ & $1.32 \pm 0.08$ & $53.36 \pm 0.07$ & $2.31 \pm 0.06$ & $57.25 \pm 0.02$ & $1.07 \pm 0.02$ & $32.49 \pm 0.10$ \\
6 & Linalool & n.d & n.d & n.d & n.d & n.d & n.d & n.d \\
7 & $\alpha$-Thujene & n.d & $18.47 \pm 0.08$ & $11.29 \pm 0.06$ & $13.28 \pm 0.03$ & $15.33 \pm 0.04$ & $13.26 \pm 0.09$ & $20.17 \pm 0.01$ \\
8 & Camphor & n.d & $2.32 \pm 0.08$ & n.d & $2.22 \pm 0.03$ & n.d & n.d & n.d \\
9 & Menthol & n.d & n.d & n.d & n.d & n.d & n.d & n.d \\
10 & Methyl chavicol & n.d & n.d & $2.09 \pm 0.06$ & n.d & n.d & n.d & n.d \\
11 & Caryophyllene E & n.d & n.d & n.d & n.d & n.d & $2.28 \pm 0.10$ & n.d \\
12 & $\alpha$-Humulene & $1.24 \pm 0.09$ & n.d & $3.17 \pm 0.09$ & n.d & $2.48 \pm 0.08$ & n.d & n.d \\
\hline
\end{tabular}

n.d., not detected

Malecky et al. (2012) examined the terpenoid content of goat blood plasma by dynamic SPME sampling. In both studies, it was found that the consumed food has an effect on the quantity and quality of terpenes in the blood of animals.

\section{Terpenes in Cheese Samples}

The chemical analysis by the HS-SPME method results of fresh and matured natural and herbal Trappist cheese of
2 cows fed with herbal feed are given in Table 8, where the compounds are listed in order of their elution from the RTX-5 column. HS-SPME-GC-MS analysis led to the identification of 6 terpenes components (alpha-pinene, myrcene, limonene, gamma-terpinene, linalool and alpha-humulene) from the fresh natural, and 12 terpenes from fresh herbal Trappist cheese. Compared to the control sample (fresh natural cheese), the fresh herbal Trappist cheese contained the previous terpenes and also six more as alpha-thujene,

Table 7 Terpenes (+) and retention time of terpenes identified by HS-SPME-GC-MS technique in the blood plasma of cows fed with various herbs

\begin{tabular}{|c|c|c|c|c|c|c|c|c|c|}
\hline No & Volatile component & $\mathrm{t}_{\mathrm{R}}(\min )$ & Control & Milfoil & $\begin{array}{l}\text { Hyssop, sage, } \\
\text { woodruff }\end{array}$ & Camomile & Goat's rue & Ribgrass & $\begin{array}{l}\text { Hay with } \\
\text { wild } \\
\text { thyme }\end{array}$ \\
\hline 1 & $\alpha$-Thujene & 7.42 & - & + & - & - & + & - & - \\
\hline 2 & $\alpha$-Pinene & 7.65 & + & + & + & + & + & + & + \\
\hline 3 & Camphene & 8.15 & + & - & + & - & - & - & - \\
\hline 4 & Sabinene & 9.00 & - & - & + & - & + & - & + \\
\hline 5 & $\beta$-Pinene & 9.10 & - & - & + & - & + & - & + \\
\hline 6 & p-Cymene & 10.97 & - & + & - & + & + & - & + \\
\hline 7 & Limonene & 11.10 & + & + & + & - & + & + & + \\
\hline 8 & 1,8-Cineole & 11.23 & - & + & - & - & - & - & - \\
\hline 9 & $\alpha$-Thujone & 15.22 & - & + & - & - & - & - & - \\
\hline 10 & $\beta$-Thujone & 15.69 & - & + & - & - & - & - & - \\
\hline 11 & Camphor & 16.18 & - & + & - & - & - & - & - \\
\hline 12 & Trans-pinocamphone & 16.87 & - & + & - & - & - & - & - \\
\hline 13 & Cis-pinocamhone & 17.50 & - & + & + & - & - & - & - \\
\hline 14 & $\alpha$-Terpineol & 18.32 & - & + & + & - & - & - & - \\
\hline 15 & Bornil-acetate & 22.50 & - & + & + & - & - & - & - \\
\hline 16 & Caryophyllene E & 28.22 & - & - & + & - & - & - & + \\
\hline 17 & $\alpha$-humulene & 29.67 & + & - & + & - & + & + & - \\
\hline
\end{tabular}


Table 8 Peak areas of the volatile terpenes identified in the SIM ion chromatogram $(\mathrm{m} / \mathrm{z} 93+119)$ recorded by HS-SPME-GC-MS technique of headspace of fresh and 6-week maturation of natural and herbal Trappist cheeses, as well as peak area ratios of herbal and natural cheeses (RSd 10\%)

\begin{tabular}{|c|c|c|c|c|c|c|c|}
\hline No & Volatile component & $\begin{array}{l}\text { Natural Trap- } \\
\text { pist }\left(\times 10^{5}\right)\end{array}$ & $\begin{array}{l}\text { Herbal Trappist } \\
\left(\times 10^{5}\right)\end{array}$ & $\begin{array}{l}\text { Area propor- } \\
\text { tions }(\mathrm{Gy} / \mathrm{N})\end{array}$ & $\begin{array}{l}\text { Mature natural } \\
\text { Trappist }\left(\times 10^{5}\right)\end{array}$ & $\begin{array}{l}\text { Mature herbal } \\
\text { Trappist }\left(\times 10^{5}\right)\end{array}$ & $\begin{array}{l}\text { Area propor- } \\
\text { tions }(\mathrm{Gy} / \mathrm{N})\end{array}$ \\
\hline 1 & $\alpha$-Thujene & n.d & 0.57 & - & n.d & n.d & - \\
\hline 2 & $\alpha$-Pinene & 0.67 & 9.49 & 14.16 & 2.96 & 6.49 & 2.19 \\
\hline 3 & Sabinene & n.d & 1.46 & - & 0.49 & 0.75 & 1.53 \\
\hline 4 & $\beta$-Pinene & n.d & 3.34 & - & 1.50 & 4.71 & 3.14 \\
\hline 5 & Myrcene & 1.95 & 0.56 & 0.29 & 10.2 & 20.7 & 2.03 \\
\hline 6 & $\alpha$-Phellandrene & n.d & 0.99 & - & n.d & n.d & - \\
\hline 7 & p-Cymene & n.d & 0.99 & - & 11.9 & 30.2 & 2.54 \\
\hline 8 & Limonene & 40.3 & 11.5 & 0.29 & 255 & 750 & 2.94 \\
\hline 9 & $\gamma$-Terpinene & 1.78 & 1.01 & 0.57 & 2.69 & 8.75 & 3.25 \\
\hline 10 & Linalool & 0.94 & 0.48 & 0.51 & 1.60 & 3.72 & 2.33 \\
\hline 11 & t-Pinocamphone & n.d & n.d & - & 6.08 & 15.4 & 2.53 \\
\hline 12 & c-Pinocamphone & n.d & n.d & - & 9.10 & 29.6 & 3.25 \\
\hline 13 & Bornil-acetate & n.d & n.d & - & 0.32 & 3.75 & 11.7 \\
\hline 14 & Caryophyllene E & n.d & 5.55 & - & n.d & n.d & - \\
\hline 15 & $\alpha$-Humulene & 0.50 & 4.36 & 8.72 & 1.20 & 1.33 & 1.11 \\
\hline
\end{tabular}

n.d., not detected

sabinene, beta-pinene, alpha-phellandrene, para-cymene and caryophyllene E (Figs. 3 and 4).

Comparing the area proportions of the chromatography peaks of fresh natural and herbal Trappist cheese, it was realised that six compounds had a significant increase in the peak area of the alpha-pinene, myrcene, limonene, gamma-terpinene, linalool and alpha-humulene in the case of fresh herbal Trappist cheese. The results prove that the amount of the identified volatile components in the test cheese (herbal Trappist cheese) increased by approximately two to three times compared to the control sample (natural Trappist cheese).
In the case of ripened cheeses, it was also observed that the control samples contained twice or three times less terpene than the herbal cheese samples. Comparing the content of terpenes in fresh and matured Trappist cheeses, it was determined that the content of terpenes in matured cheeses has increased significantly, because cheeses lose water during ripening, resulting in a more concentrated texture and a higher concentration of analytes. Therefore, previously undetectable terpene compounds appeared in matured cheeses (e.g. bornyl-acetate). In some cases, terpenes disappeared during the ripening, probably because they were
Fig. 3 HS-SPME-GC-MS ion chromatogram of natural Trappist cheese $(\mathrm{m} / \mathrm{z}=93+119)$. (2: $\alpha$-pinene, 5 : myrcene, 8 : limonene, 9: $\gamma$-terpinene, 10: linalool, 11: $\alpha$-humulene)

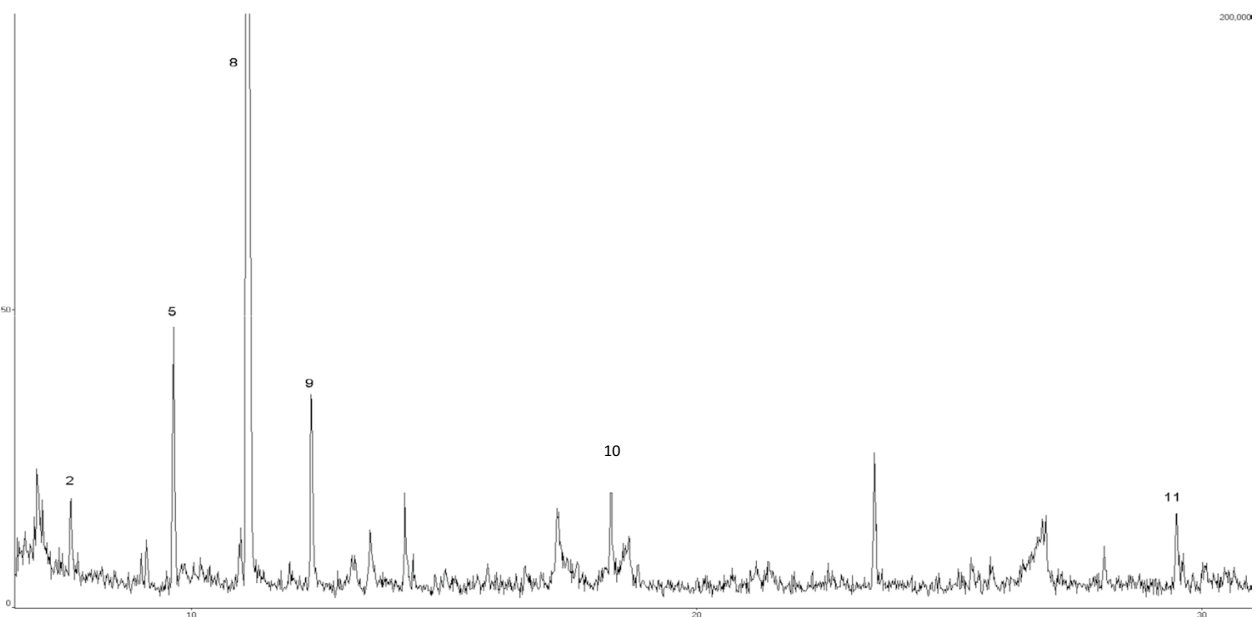


Fig. 4 HS-SPME-GC-MS ion chromatogram of herbal Trappist cheese $(\mathrm{m} / \mathrm{z}=93+119)$. (1: $\alpha$-thujene, 2: $\alpha$-pinene, 3: sabinene, 4 : $\beta$-pinene, 5: myrcene, 6: $\alpha$-phellandrene, 7: para-cymene, 8: limonene, 9: $\gamma$-terpinene, 10: linalool, 11: caryophyllene E, 12: $\alpha$-humulene)

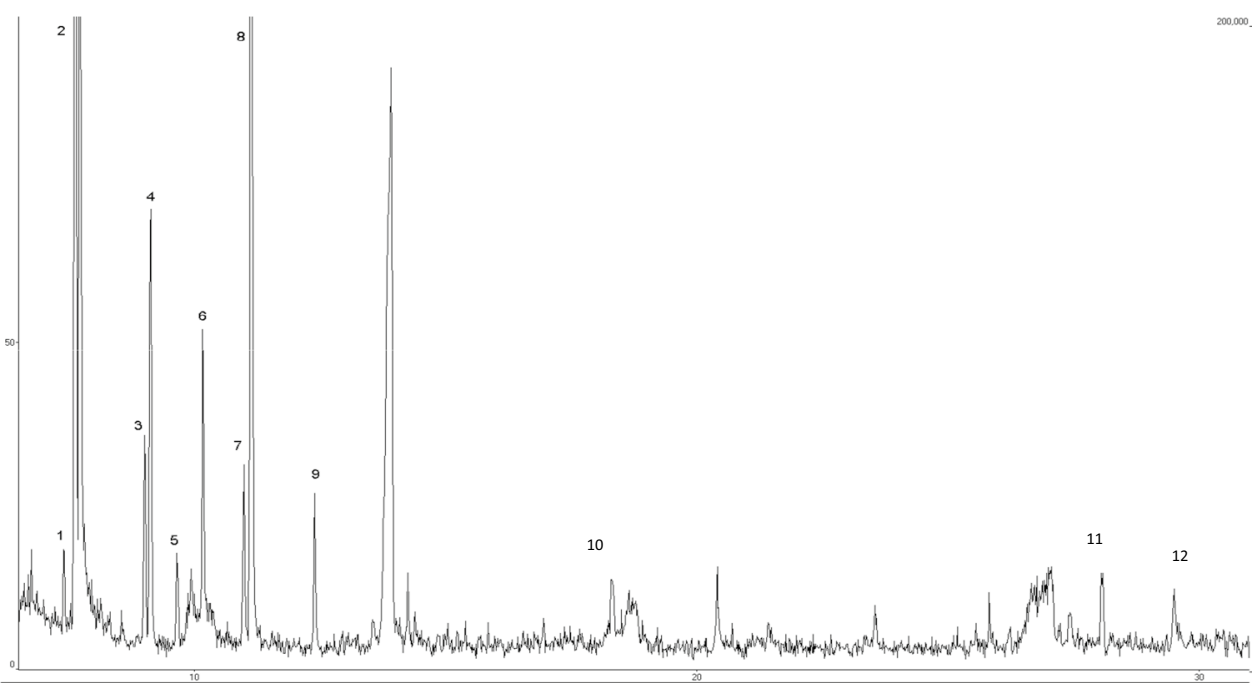

decayed (e.g. alpha-thujene, alpha-phellandrene and caryophyllene E).

Delgado et al. (2011) investigated the terpene composition of goat cheeses by the HS-SPME-GC-MS method. The DIV/CAR/PDMS fibre recommended by the manufacturer was used for sampling. Among the terpenes we examined, they were able to detect limonene and cymol. Ziino et al. (2005) examined "Provola dei Nebrodi" cheeses by the SPME-GC-MS method and identified limonene as a typical terpene compound in the cheeses. According to Viallon et al. (1999), hydrocarbons, especially limonene, are derived directly from cow feed into cheeses. This statement also supports the conclusion that the said monoterpene is also present in cheeses made from the milk of control individuals. Chion et al. (2010) examined the terpene profile of "Toma piemontese" cheeses depending on the seasons. The terpene composition of cheeses made in different seasons showed a difference, and the terpene profile of the cheeses reflected the terpene profile of the cheese milk, thus proving that terpenes can be transferred from milk to cheeses.

\section{Conclusions}

Based on this study, it can be clearly stated that terpene solutions of herbal origin may pass from the dairy animals' blood not only into the animals' milk and their milk fat but also into the cheese prepared from their milk.

The developed GC-MS method is suitable for the separation and identification of volatile terpenes in milk and milk products by the SIM method. We examined the dependence of the amount of terpenes dissolved in the SPME film on the sampling temperature and its time during SPME sampling. We determined the optimal sampling temperature and time for the SPME procedure, and the sensitivity, repeatability and limit of detection of our developed SPME-GC-MS method for each terpene. Our results demonstrate that there has been a significant increase in the number of terpene compounds in milk derived from cows or goats witch consuming herbs. In the study, we successfully determined the concentrations of terpene compounds from the milk fat of cows as well as directly from goat milk by the SPME-GC-MS method.

It also verifies that during herbal nutrition, many active ingredients pass through the blood plasma into the milk of the dairy animals and the dairy products made from them. That is how it was proven as well that by feeding with the inclusion of herbs, it is possible to produce such raw materials for processing plants, by the developed and applied analytical procedure, which favourably affects the characteristics of dairy products, particularly of cheeses.

Acknowledgements The project was supported by the European Union and co-financed by the European Social Fund (grant agreement no. EFOP-3.6.1-16-2016-00024, project title: Innovations for Intelligent Specialisation on the University of Veterinary Science and the Faculty of Agricultural and Food Sciences of the Széchenyi István University Cooperation).

Author Contribution R. Szekelyhidi: taking measurements, data processing.

B. Sik: data processing.

E. Hanczné Lakatos: project manager, head of department.

Zs. Ajtony: supervisor.

Funding Open access funding provided by Széchenyi István University (SZE). The project was supported by the European Union and co-financed by the European Social Fund (grant agreement no. EFOP-3.6.1-16-2016-00024.) 
Data Availability Not applicable.

Code Availability Not applicable.

\section{Declarations}

Conflict of Interest Rita Székelyhidi declares that she has no conflict of interest. Erika Hanczné Lakatos declares that she has no conflict of interest. Beatrix Sik declares that she has no conflict of interest. Zsolt Ajtony declares that he has no conflict of interest.

Informed Consent Not applicable.

Open Access This article is licensed under a Creative Commons Attribution 4.0 International License, which permits use, sharing, adaptation, distribution and reproduction in any medium or format, as long as you give appropriate credit to the original author(s) and the source, provide a link to the Creative Commons licence, and indicate if changes were made. The images or other third party material in this article are included in the article's Creative Commons licence, unless indicated otherwise in a credit line to the material. If material is not included in the article's Creative Commons licence and your intended use is not permitted by statutory regulation or exceeds the permitted use, you will need to obtain permission directly from the copyright holder. To view a copy of this licence, visit http://creativecommons.org/licenses/by/4.0/.

\section{References}

Abilleira E, Renobales M, Nájera AI, Virto M, Ruiz de Gordoa JC, Pérez-Elortondo FJ, Albisu M, Barron LJR (2010) An accurate quantitative method for the analysis of terpenes in milk fat by headspace solid-phase microextraction coupled to gas chromatography-mass spectrometry. Food Chem 120:1162-1169. https:// doi.org/10.1016/j.foodchem.2009.11.050

Borge GIA, Sandberg E, Øyaas J, Abrahamsen RK (2016) Variation of terpenes in milk and cultured cream from Norwegian alpine rangeland-fed and in-door fed cows. Food Chem 199:195-202. https://doi.org/10.1016/j.foodchem.2015.11.098

Boyle RR, McLean S, Brandon S, Pass GJ, Davies NW (2002) Application of solid-phase microextraction to the quantitative analysis of 1,8-cineole in blood and expired air in a Eucalyptus herbivore, the brushtail possum (Trichosurus vulpecula). J Chromatogr B 78:0397-0406. https://doi.org/10.1016/s1570-0232(02)00625-6

Buchin S, Martin B, Dupont D, Bornard A, Achilleos C (1999) Influence of the composition of Alpine highland pasture on the chemical and rheological and sensory properties of cheese. J Dairy Res 66:579-588. https://doi.org/10.1017/s0022029999003842

Buchin S, Salmon J-C, Carnat A-P, Berger T, Bugaud C, Bosset JO (2002) Identification de composés monoterpéniques, sesquiterpéniques et benzéniques dans un lait d'alpage trés riche en ces substances. Mitt Lebensmittelunters Hyg 93:199-216

Bugaud C, Buchin S, Coulon J-B, Hauwuy A, Dupont D (2001a) Influence of the nature of alpine pastures on plasmine activity, fatty acide and volatile compounds composition of milk. Lait 81:401414. https://doi.org/10.1051/lait:2001140

Bugaud C, Buchin S, Nöel Y, Tessier L, Pochet S, Martin B, Chamba JF (2001b) Relationships between abundance cheese texture, its composition and that of milk produced by cows grazing different types of pastures. Lait 81:593-607. https://doi.org/10.1051/lait:2001152

Cais-Sokolińska D, Majcher M (2010) Sensory properties and volatile composition of full and non-fat cheese produce from curd-ripened fried acid tvarog. Acta Aliment Hung 39:69-80. https://doi.org/ 10.1556/AAlim.39.2010.1.7

Chion AR, Tabacco E, Giaccone D, Peiretti PG, Battelli G, Borreani $G$ (2010) Variation of fatty acid and terpene profiles in mountain milk and "toma piemontese" cheese as affected by diet composition in different seasons. Food Chem 121:393-399. https://doi. org/10.1016/j.foodchem.2009.12.048

Collomb M, Butikofer U, Spahni M, Jeangros B, Bosset JO (1999) Fatty acid and glyceride composition of cow's milk fat in highand lowland regions. Sci Aliment 19:97-110

Cornu A, Carnat A-P, Martin B, Coulon J-B, Lamaison J-L, Berdagué J-L (2001) Solid-phase microextraction of volatile components from natural grassland plants. J Agric Food Chem 49:203-209. https://doi.org/10.1021/jf0008341

De Frutos M, Sanz J, Martinez-Castro I (1991) Characterization of artisanal cheeses by GC and GC/MS analysis of their medium volatility (SDE) fraction. J Agric Food Chem 39:524-530. https:// doi.org/10.1021/jf00003a019

De Noni I, Battelli G (2008) Terpenes and fatty acid profiles of milk fat and "Bitto" cheese as affected by transhumance of cows on different mountain pastures. Food Chem 109:299-309. https:// doi.org/10.1016/j.foodchem.2007.12.033

Delgado FJ, González-Crespo J, Cava R, Ramírez R (2011) Formation of the aroma of a raw goat milk cheese during maturation analysed by SPME-GC-MS. Food Chem 129:1156-1163. https://doi.org/ 10.1016/j.foodchem.2011.05.096

Dumont JP, Adda J (1978) Occurrence of sesquiterpenes in mountain cheese volatiles. J Agric Food Chem 26:364-367. https://doi.org/ $10.1021 / \mathrm{jf} 60216 \mathrm{a} 037$

Erkaya T, Şengül M (2011) Comparison of volatile compounds in yoghurts made from cows', buffaloes', ewes' and goats' milks. Int J Dairy Technol 64:40-246. https://doi.org/10.1111/j.14710307.2010.00655.x

Fernandez C, Astier C, Rock E, Coulon J-B, Berdagué J-L (2003) Characterization of milk by analysis of its terpene fractions. Int $\mathrm{J}$ Food Sci Tech 38:445-451. https://doi.org/10.1046/j.1365-2621. 2003.00708.x

Fernández-García E, Imhof M, Schlichtherle-Cerny H, Bosset JO, Nuñez M (2008) Terpenoids and benzenoids in La Serena cheese made at different seasons of the year with a Cynara cardunculus extract as coagulant. Int Dairy J 18:147-157. https://doi.org/10. 1016/j.idairyj.2007.08.007

Grandison AS, Manning DJ, Thomson DJ, Anderson M (1985) Chemical composition, rennet coagulation properties and flavour of milks from cows grazing ryegrass or white clover. J Dairy Res 52:33-39. https://doi.org/10.1017/S0022029900023025

Guichard E, Berdague J, Grappin R (1987) Affinage et qualité du Gruyère de Comté. Influence de l'affinage sur la teneur en composés volatils. Lait 67:319-338. https://doi.org/10.1051/lait:1987319

Estell RE, Utsumi SA, Cibils AF (2010) Measurement of monoterpenes and sesquiterpenes in serum, plasma and rumen fluid from sheep. Anim Feed Sci Technol 158:104-109. https://doi.org/10.1016/j. anifeedsci.2010.03.011

Ho TD, Canestraro AJ, Anderson JL (2011) Ionic liquids in solid-phase microextraction: a review. Anal Chim Acta 695:18-43. https://doi. org/10.1016/j.aca.2011.03.034

Jeangros B, Troxler J, Conod D, Scheovic J, Bosset JO, Bütikofer U, Gauch R, Mariaca R, Pauchard JP, Sieber R (1997) Etude des relations entre les caractéristiques des erbages et celles du lait, de la crème et du fromage de type L'Etivaz ou Gruyère. Rev Suisse Agric 29:23-34

Lubbers S, Landy P, Voilley A (1998) Retention and release of aroma compounds in food containing proteins. Food Tech 52(68-72):208-214

Majcher M, Qawrowski P, Jeleń H (2010) Comparison of original and adulterated oscypek cheese based on volatile and sensory 
profiles. ACTA Scientiarum Polonorum e Technologia Alimentaria 9:265-275

Malecky M, Broudiscou A, Broudiscou LP (2012) Optimisation of headspace solid-phase microextraction for quantitative analysis of monoterpenes in caprine blood. Anim Feed Sci Tech 173:261267. https://doi.org/10.1016/j.anifeedsci.2012.02.002

Mariaca RG, Bosset JO (1997) Instrumental analysis of volatile (flavour) compounds in milk and dairy products. Lait 77:13-40. https://hal.archives-ouvertes.fr/hal-00929514/document

Mariaca RG, Berger TFH, Gauch R, Imhof MI, Jeangros B, Bosset JO (1997) Occurrence of volatile mono- and sesquiterpenoids in highland and lowland plant species as possible precursors for flavour compounds in milk and dairy products. J Agr Food Chem 45:4423-4434. https://doi.org/10.1021/jf970216t

Panseri S, Giani I, Mentasti T, Bellagamba F, Caprino F, Moretti VM (2008) Determination of flavour compounds in a mountain cheese by headspace sorptive extraction-thermal desorption-capillary gas chromatography-mass spectrometry. LWT 41:185-192. https:// doi.org/10.1016/j.lwt.2007.02.011

Poulopoulou I, Zoidis E, Massouras T, Hadjigeorgiou I (2012a) Terpenes transfer to milk and cheese after oral administration to sheep fed indoors. J Anim Physiol an n 96:172-181. https://doi.org/10. 1111/j.1439-0396.2011.01128.x

Poulopoulou I, Zoidis E, Massouras T, Hadjigeorgiou I (2012b) Transfer of orally administered terpenes in goat milk and cheese. Asian Austral J Anim 25:1411-1418. https://doi.org/10.5713/ajas.2012.12165
Scehovic J, Jeangros B, Troxler J, Bosset JO (1998) Effets de la composition botanique des herbages patur es sur quelques composants des fromages de type L'Etivaz ou Gruyere. Rev Suisse Agric 30:167-171

Schlichtherle-Cerny H, Imhof MI, Fernández-Garciá E, Bosset JO (2004) Changes in terpene composition from pasture to cheese. Cheese art., in: 6th International Meeting on Mountain Cheese, Ragusa, Italy. CD-ROM. Corfilac Edition.

Sides A, Robards K, Helliwell S (2000) Developments in extraction techniques and their application to analysis of volatiles in foods. Trends Anal Chem 19:322-329. https://doi.org/10.1016/S01659936(99)00225-3

Viallon C, Verdier-Metz I, Denoyer C, Pradel P, Coulon J-B, Berdagué J-L (1999) Desorbed terpenes and sesquiterpenes from forages and cheeses. J Dairy Res 66:319-326. https://doi.org/10.1017/ S0022029999003520

Viallon C, Martin B, Verdier-Metz I, Pradel P, Garel J-P, Coulon J-B, Berdagué J-L (2000) Transfer of monoterpenes and sesquiterpenes from forages into milk fat. Lait 80:635-641. https://doi.org/10. 1051/lait:2000150

Ziino M, Condurso C, Romeo V, Giuffrida D, Verzera A (2005) Characterization of "Provola dei Nebrodi", a typical Sicilian cheese, by volatiles analysis using SPME-GC/MS. Int Dairy J 15:585-659. https://doi.org/10.1016/j.idairyj.2004.07.024

Publisher's Note Springer Nature remains neutral with regard to jurisdictional claims in published maps and institutional affiliations. 